\title{
Chemical Behaviour of Tc(IV) Complexes under Alpha Irradiation in Chloride Media
}

\author{
F. Poineau, M. Fattahi,* and B. Grambow \\ SUBATECH UMR 6457 (Université de Nantes, Ecole des Mines, IN2P3/CNRS), 4 rue Alfred Kastler, BP 20722, \\ F-44307 Nantes cedex 03, France
}

Received: July 31, 2005; In Final Form: September 30, 2005

In order to study the stability of Tc(IV) complexes in chloride media under alpha radiation produced by a cyclotron, an electrochemical cell was developed. In this cell, the stability of $\mathrm{TcCl}_{6}^{2-}, \mathrm{TcCl}_{5}\left(\mathrm{H}_{2} \mathrm{O}\right)^{-}, \mathrm{Tc}_{2} \mathrm{OCl}_{10}{ }^{4-}, \mathrm{Tc}_{\mathrm{n}} \mathrm{O}_{\mathrm{y}}{ }^{(4 \mathrm{n}-}$ ${ }^{2 y)+}$ and $\mathrm{TcO}_{2} \cdot \mathrm{xH}_{2} \mathrm{O}$ were studied in $3 \mathrm{M}$ chloride media with a $\mathrm{pH}$ range from 0.3 to 2.5 . The stability of a $\left(\mathrm{TcCl}_{6}{ }^{2-} / \mathrm{TcCl}_{5}\left(\mathrm{H}_{2} \mathrm{O}\right)^{-} / \mathrm{Tc}_{2} \mathrm{OCl}_{10}{ }^{4-}\right)$ mixture was also investigated during alpha irradiation under a constant current. These studies showed that $\mathrm{TcCl}_{6}{ }^{2-}$ is a very stable compound whereas chloro-oxygenated compounds were oxidized to Tc(VII). Consequently, the relative stabilities of the Tc(IV) complexes in $3 \mathrm{M}$ chloride media under alpha irradiation was determined.

\section{Introduction}

One option retained for management of nuclear waste is storage in deep underground which presents naturally reducing conditions (absence of oxygen and reducing potential). Nevertheless, the presence of nuclear waste and its radiation associated may lead to the radiolysis of the surrounding media and to the formation of radiolytic compounds. Among these nuclear wastes, ${ }^{99} \mathrm{Tc}$ is considered as one of the most important fission products: it represents $10 \%$ of the mass of fission product and has an important toxicity $\left(\mathrm{T}_{1 / 2}=2.01 \times 10^{5} \mathrm{y}, \beta^{-}\right.$emitter $)$. That is why studies on the behaviour of technetium are of great importance.

In the storage media, Tc could be present in Tc(IV) or even Tc(III) forms. The behaviour of Tc under radiation depends on the radiolytic species formed : in presence of organic compounds (formate, ${ }^{1}$ EDTA, ${ }^{2}$ alcohol t-butyl ${ }^{3,4}$ ) radiolysis leads to the reduction of $\mathrm{Tc}(\mathrm{VII})$ to $\mathrm{Tc}(\mathrm{IV})$ and formation of colloids or polymers whereas in non organic media, oxidation of Tc(IV) to Tc(VII) is observed. ${ }^{5,6}$

After 10000 years of deposit, alpha emitters will be the preponderant radioactive elements in the spent fuel. Then alpha radiolysis will be the dominant radiolytic process. After this period, ${ }^{99} \mathrm{Tc}$ will also be present in the spent fuel and in the case of an alteration of the confinement barrier, the Tc species could be in contact with the water radiolysis products. In this context, the stability of Tc(IV) complexes under alpha radiation was studied in aqueous media.

Many researches on the speciation of Tc(IV) were carried out in chloride media. Recent studies ${ }^{7,8}$ have shown that speciation of $\mathrm{Tc}(\mathrm{IV})$ between $\mathrm{pH}=0$ and $\mathrm{pH}=2.5$ is dominated by polymeric species. For this reason, in our work, the stability of Tc(IV) complexes was studied in $3 \mathrm{M}$ chloride. These studies were carried out under alpha radiation produced by a cyclotron. Furthermore, an electrochemical cell was specially developed: it was used to study the stability of Tc(IV) complex under alpha radiation. It has also been used in other works to study influence of alpha radiolysis on the stability of $\mathrm{UO}_{2}$ (Ref. 9) and nuclear glass. ${ }^{10}$

In this work, we present the effects of alpha radiation on $\mathrm{Tc}$ (IV) stability in chloride media in absence and presence of an electrochemical potential.

*Corresponding author. E-mail: fattahi@subatech.in2p3.fr. FAX: $+33-2-5185-8452$.

\section{Experimental}

2.1. Electrochemical cell and experimental set-up. Alpha irradiation by a cyclotron has already been used to study the influence of alpha radiolysis on stabilities of radio-elements. ${ }^{11}$ The experimental set-up was composed of electrochemical cells which presented a reduced volume in order to minimize dilution of radiolytic product. Those cells have an optical window with a thickness $<500 \mu \mathrm{m}$ that allowed the transmission of alpha particles.

The cell developed for ours studies, presents a volume of 30 $\mathrm{ml}$ and an optical window made of silica with a thickness of $130 \pm 10 \mu \mathrm{m}$. The cell (Figure 1) consists of: a reactional block for solution, a cover used to maintain the electrochemical system and a collimator.

The collimator $(\varnothing 6 \mathrm{~mm})$ was designed in order to focus alpha beam through solution. It also permits to maintain the optical window whose tightness is assured by an O-ring. The solutions were homogenized by a magnetic stirrer and permanently purged by Argon bubbling during irradiation.

The electrochemical system is composed of 3 electrodes purchased from Radiometer Analytical, S.A. The working electrode

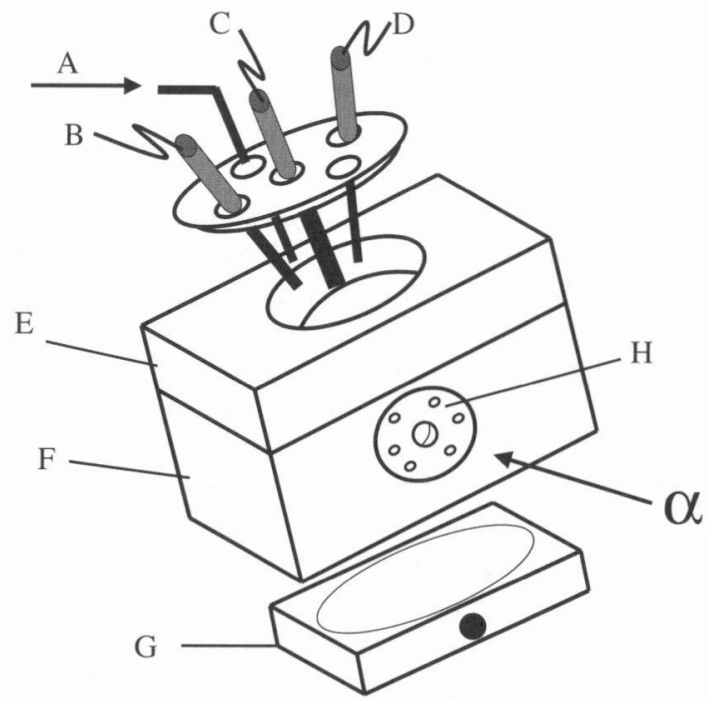

Figure 1. Set-up used for alpha radiolysis experiment.

A: argon bubbling, B: auxiliary electrode, C: working electrode, D: reference electrode, $\mathbf{E}$ : cover, $\mathbf{F}$ : reactional block, $\mathbf{G}$ : magnetic stirrer and $\mathbf{H}$ : collimator. 
(XR 140) is made of a platinum plate $(1 \mathrm{~cm} \times 4 \mathrm{~cm})$. The auxiliary electrode (XR 110) is constituted of a platinum plate $(5 \mathrm{~mm}$ $\times 5 \mathrm{~mm}$ ). This electrode is installed in a lounge (Al 120) in order to isolate oxidation products that may form at this electrode during reactions. The reference electrode is an $\mathrm{Ag} / \mathrm{AgCl}$ electrode (XR 300), $\mathrm{E}=248 \mathrm{mV} / \mathrm{ENH}$ ).

These electrodes were installed on a glass cover $\mathrm{CP} 4 \mathrm{R}$ which was settled and screwed on the cell cover. This electrochemical system was connected to a PGP 201 potentiometer equipped with voltamaster 4 , which allows to work under constant current or potential and provides analyses by cyclic voltammetry. This experimental set-up was then settled on an ionisation chamber and controlled from the outside of the cyclotron alveolus through large coaxial cables.

Alpha irradiation was performed at the CERI cyclotron (CNRS-Orleans). This cyclotron generates alpha particles $\left({ }^{4} \mathrm{He}^{2+}\right)$ in an energy range from $5 \mathrm{MeV}$ to $45 \mathrm{MeV}$. Energy of $28 \mathrm{MeV}$ was chosen for all the Tc experiments. The calculations from SRIM2000 code indicated that ${ }^{4} \mathrm{He}^{2+}(28 \mathrm{MeV})$ passed into the cell carrying energy of $5-6 \mathrm{MeV}$ and a penetration depth in solution about $45 \mu \mathrm{m}$. The rest of energy was absorbed by the cell window and by the titanium windows of the ionization chamber. The alpha beam was monitored during the experiments as a function of the measured ${ }^{4} \mathrm{He}^{2+}$ current on the ionisation chamber. During all the experiments, the current of ${ }^{4} \mathrm{He}^{2+}$ flux in solution was fixed in the range from $10 \mathrm{nA}$ to 50 $\mathrm{nA}$. The irradiation time depending of experience, vary between $5 \mathrm{mn}$ to $40 \mathrm{mn}$. The duration of an experiment is around $1 \mathrm{~h} 30$.

2.2. Dosimetry and $\mathrm{H}_{2} \mathrm{O}_{2}$ measurement. Doses were measured using the Fricke's dosimetry ${ }^{12}$ which is based on the oxidation of $\mathrm{Fe}$ (II) to $\mathrm{Fe}$ (III) by water radiolysis products. The $\mathrm{Fe}(\mathrm{II})$ solution used was $1 \mathrm{mM} \mathrm{FeSO}_{4}$ prepared in a $0.4 \mathrm{M}$ $\mathrm{H}_{2} \mathrm{SO}_{4}$ solution. The concentration of $\mathrm{Fe}$ (III) was then determined by UV-Vis measurement at $304 \mathrm{~nm}\left(\varepsilon=2197 \mathrm{M}^{-1} \mathrm{~cm}^{-1}\right)$. The radiolytic yield $\mathrm{G}(\mathrm{Fe}(\mathrm{III}))$ used for the dose calculations was $1.0610^{-6} \mathrm{~mol}$. $\mathrm{J}^{-1}$

The concentrations of $\mathrm{H}_{2} \mathrm{O}_{2}$ produced during the irradiation were measured using the Ghormley's method ${ }^{13}$ which is based on oxidation of $\mathrm{I}^{-}$to $\mathrm{I}_{3}{ }^{-}$by $\mathrm{H}_{2} \mathrm{O}_{2}$. The $1 \mathrm{mM}$ iodide solution, used in this work, was prepared by dissolving $\mathrm{KI}$ in a $0.1 \mathrm{M}$ $\mathrm{NaOH}$ solution. The measurement protocol is showed as follows: 1) A phthalate buffer solution $(\mathrm{pH}=6)$ was added to the KI solution. 2) The $\left[\mathrm{I}_{3}{ }^{-}\right]$was then determined by UV-Vis measurement at $350 \mathrm{~nm}\left(\varepsilon=28000 \mathrm{M}^{-1} \mathrm{~cm}^{-1}\right)$. 3) The concentration of $\mathrm{H}_{2} \mathrm{O}_{2}$ in solution was finally determined from the concentration of $\mathrm{I}_{3}^{-}$.

2.3. Chemical and Sample preparation. The $\mathrm{NaTcO}_{4}$ solution used for all syntheses was purchased from Cerca, Co France. All chemicals used are of analytical purity and all solutions were prepared with Milli-Q water.

The stock solution of $\mathrm{TcCl}_{6}{ }^{2-}(0.02 \mathrm{M}, 6 \mathrm{M} \mathrm{HCl})$ was prepared by heating $\mathrm{TcO}_{4}{ }^{-}$at $90{ }^{\circ} \mathrm{C}$ in concentrated $\mathrm{HCl}$. The stock solution was kept in the dark at an inert gas glove box.

The stock solution of $\mathrm{Tc}_{2} \mathrm{OCl}_{10}{ }^{4-}(8.8 \mathrm{mM})$ in $\left[\mathrm{Cl}^{-}\right]=3 \mathrm{M}$, $\mathrm{pH}=0.3$ was synthesised by using the method recently developed. ${ }^{8}$ The $\mathrm{TcCl}_{6}{ }^{2-} / \mathrm{Tc}_{2} \mathrm{OCl}_{10}{ }^{4-}$ mixture in $3 \mathrm{M}$ chloride solution $\left(\mathrm{pH}=0.3,[\mathrm{Tc}]=10.95 .10^{-5} \mathrm{M}\right)$ was prepared from $\mathrm{Tc}_{2} \mathrm{OCl}_{10}{ }^{4-}$ and $\mathrm{TcCl}_{6}^{2-}$ stock solutions.

$\mathrm{The} \mathrm{Tc}_{\mathrm{n}} \mathrm{O}_{\mathrm{y}}{ }^{(4 \mathrm{n}-2 \mathrm{y})+} / \mathrm{TcO}_{2} \cdot \mathrm{xH}_{2} \mathrm{O}$ solution was prepared by diluting $\mathrm{TcCl}_{6}{ }^{2-}$ in a medium of $\left[\mathrm{Cl}^{-}\right]=3 \mathrm{M}$ and $\mathrm{pH}=1$. The $\mathrm{pH}$ was adjusted to 2.5 by $\mathrm{NaOH}$. The solution was kept in an inert gas glove box, sealed and carried to Orleans cyclotron facility under inert atmosphere to avoid oxidation.

The mixture $\mathrm{TcCl}_{6}{ }^{2-} / \mathrm{TcCl}_{5}\left(\mathrm{H}_{2} \mathrm{O}\right)^{-} / \mathrm{Tc}_{2} \mathrm{OCl}_{10}{ }^{4-}$ used for experiment under constant current was synthesised by reduction $(\mathrm{i}=-500 \mu \mathrm{A})$ of $\mathrm{TcO}_{4}{ }^{-}$in the electrochemical cell in $3 \mathrm{M}$ chloride solution $(\mathrm{pH}=1)$.

2.4. Other techniques. ${ }^{99} \mathrm{Tc}$ analysis was performed using liquid scintillation counting: Packard 2550 TR/AB Liquid
Scintillation analyzer). The scintillation cocktail used was ULTIMA GOLD AB ${ }^{\mathrm{TM}}$ (Packard). UV-Vis spectra between each irradiation were recorded on a Shimadzu 2401 double beam spectrometer in $1 \mathrm{~cm}$ cell. Ultra pure water was used as the reference.

\section{Results}

All experiments were performed in the aim of describing the behaviour of $\mathrm{Tc}(\mathrm{IV})$ complexes under alpha irradiation. In this work, our studies were focused on $3 \mathrm{M}$ chloride media with a $\mathrm{pH}$ range from 0.3 to 2.5 since the speciation of $\mathrm{Tc}(\mathrm{IV})$ in this domain is well documented. ${ }^{7,8}$ According to their results, $\mathrm{Tc}_{2} \mathrm{OCl}_{10}{ }^{4-}$ is dominant in a $\mathrm{pH}$ range from 0 to 1 and $\mathrm{Tc}_{\mathrm{n}} \mathrm{O}_{\mathrm{y}}{ }^{(4 \mathrm{n}-2 \mathrm{y})+}$ over $\mathrm{pH}=1.3$. At $[\mathrm{Tc}]=10^{-4} \mathrm{M}, \mathrm{Tc}_{\mathrm{n}} \mathrm{O}_{\mathrm{y}}{ }^{(4 \mathrm{n}-2 \mathrm{y})+}$ begin to precipitate in $\mathrm{TcO}_{2} \cdot \mathrm{xH}_{2} \mathrm{O}$ at $\mathrm{pH}=2.2^{7}$. Thus, irradiations of $\mathrm{TcCl}_{6}{ }^{2-}$ and $\mathrm{Tc}_{2} \mathrm{OCl}_{10}{ }^{4-}$ were carried out at $\mathrm{pH}=0.3$ and those of a $\mathrm{Tc}_{\mathrm{n}} \mathrm{O}_{\mathrm{y}}{ }^{(4 \mathrm{n}-2 \mathrm{y})+} / \mathrm{TcO}_{2} \cdot \mathrm{xH}_{2} \mathrm{O}$ mixture at $\mathrm{pH}=2.5$. The stability of a $\mathrm{TcCl}_{6}{ }^{2-} / \mathrm{TcCl}_{5}\left(\mathrm{H}_{2} \mathrm{O}\right)^{-} / \mathrm{Tc}_{2} \mathrm{OCl}_{10}{ }^{4-}$ mixture in $\left[\mathrm{Cl}^{-}\right]=3 \mathrm{M}, \mathrm{pH}=$ 1 was also studied under a constant current $(\mathrm{i}=-500 \mu \mathrm{A})$.

3.1. Irradiation of $\mathrm{TcCl}_{6}{ }^{2-}$. $\mathrm{TcCl}_{6}{ }^{2-}\left(\mathrm{Tc}=9.85 \cdot 10^{-5} \mathrm{M}\right)$ was irradiated in a $3 \mathrm{M}$ chloride medium $(\mathrm{pH}=0.3)$, with a dose rate of $117.43 \mathrm{~Gy}_{\mathrm{min}}{ }^{-1}$. Changes of absorption spectra during irradiations are presented in Figure 2.

Figure 2 reveals that $\mathrm{TcCl}_{6}{ }^{2-}$ is practically stable under alpha irradiation. After irradiation with a dose of $11700 \mathrm{~Gy}$, only 4 $\%$ of $\mathrm{TcCl}_{6}{ }^{2-}$ was transformed. Thus, the initial radiolytic yield was found to be $-(3.40 \pm 1.13) \cdot 10^{-10}$ mol. $\mathrm{J}^{-1}$, which is 1000 lower than that of Fattahi et $\mathrm{al}^{5}$ under gamma radiation in the same medium.

Under the same experimental conditions, the alpha irradiation of a $3 \mathrm{M}$ chloride solution $(\mathrm{pH}=0.3)$ without $\mathrm{Tc}$ led to the apparition of a specie characterized by an absorption band at $230 \mathrm{~nm}$. According to literature data [14] this band is characteristic of the radiolytic product $\mathrm{Cl}_{3}{ }^{-}$.

3.2. Irradiation of a $\mathrm{TcCl}_{6}{ }^{2-} / \mathrm{Te}_{2} \mathrm{OCl}_{10}{ }^{4-}$ mixture. A $\mathrm{TcCl}_{6}{ }^{2-} / \mathrm{Tc}_{2} \mathrm{OCl}_{10}{ }^{4-}$ mixture $\left(\mathrm{Tc}=10.95 .10^{-5} \mathrm{M}\right)$ was irradiated in a $3 \mathrm{M}$ chloride solution $(\mathrm{pH}=0.3)$ with a dose rate of 117.43 Gy. $\mathrm{min}^{-1}$. Changes of absorption spectra during irradiations are presented in Figure 3 and the evolution of Tc species in Figure 4.

Figure 3 and 4 confirm the stability of $\mathrm{TcCl}_{6}{ }^{2-}$ and revealed that irradiation of $\mathrm{Tc}_{2} \mathrm{OCl}_{10}{ }^{4-}$ leads to its oxidation to $\mathrm{TcO}_{4}{ }^{-}$. This reaction is characterized by disappearance of the band at $354 \mathrm{~nm}\left(\varepsilon=9307 \mathrm{M}^{-1} \mathrm{~cm}^{-1}\right)$ of $\mathrm{Tc}_{2} \mathrm{OCl}_{10}{ }^{4-}$ and the apparition at $287 \mathrm{~nm}\left(\varepsilon=2316 \mathrm{M}^{-1} \mathrm{~cm}^{-1}\right)$ of the band characteristic of $\mathrm{TcO}_{4}{ }^{-}$ Consequently, the hypothesis that irradiation of $\mathrm{Tc}_{2} \mathrm{OCl}_{10}{ }^{4-}$ leads to its oxidation to $\mathrm{Tc}(\mathrm{VII})$ was proved. The initial radiolytic yields of the Tc species are presented in Table 1.

3.3. Irradiation of a $\mathrm{Tc}_{\mathrm{n}} \mathrm{O}_{\mathrm{y}}{ }^{(4 \mathrm{n}-2 \mathrm{y})+} / \mathrm{TcO}_{2} \cdot \mathrm{xH}_{2} \mathrm{O}$ mixture. A $\mathrm{Tc}_{\mathrm{n}} \mathrm{O}_{\mathrm{y}}{ }^{(4 \mathrm{n}-2 \mathrm{y})+} / \mathrm{TcO}_{2} \cdot \mathrm{xH}_{2} \mathrm{O}$ mixture $\left(\mathrm{Tc}=9.9 \cdot 10^{-5} \mathrm{M}\right)$ was irradiated in a medium of $\left[\mathrm{Cl}^{-}\right]=3 \mathrm{M}$ and $\mathrm{pH}=2.5$, with a dose rate

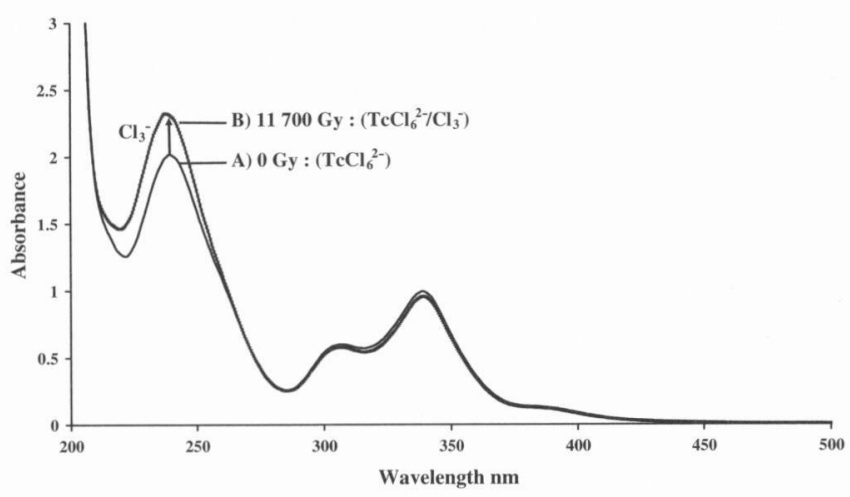

Figure 2. Change of absorption spectra of $\mathrm{TcCl}_{6}{ }^{2-}$ during alpha irradiation. Operating conditions: dose rate: $117.43 \mathrm{~Gy} \cdot \mathrm{min}^{-1}$; atmosphere argon; $[\mathrm{Tc}]=9.85 .10^{-5} \mathrm{M},\left[\mathrm{Cl}^{-}\right]=3 \mathrm{M}, \mathrm{pH}=0.3$. 


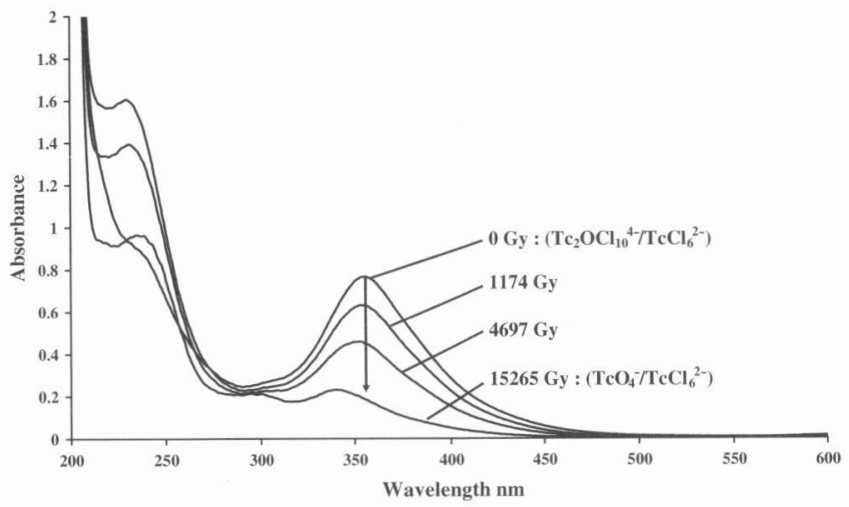

Figure 3. Change of absorption spectra of a $\mathrm{Tc}_{2} \mathrm{OCl}_{10}{ }^{4-} / \mathrm{TcCl}_{6}{ }^{2-}$ mixture during alpha irradiation. Operating conditions: dose rate: 117.43 Gy.min ${ }^{-1}$; atmosphere argon; $[\mathrm{Tc}]=10.95 .10^{-5} \mathrm{M},\left[\mathrm{Cl}^{-}\right]=3 \mathrm{M}, \mathrm{pH}=$ 0.3; doses: 0 Gy, $1174 \mathrm{~Gy}, 4697 \mathrm{~Gy}$ and $15365 \mathrm{~Gy}$.

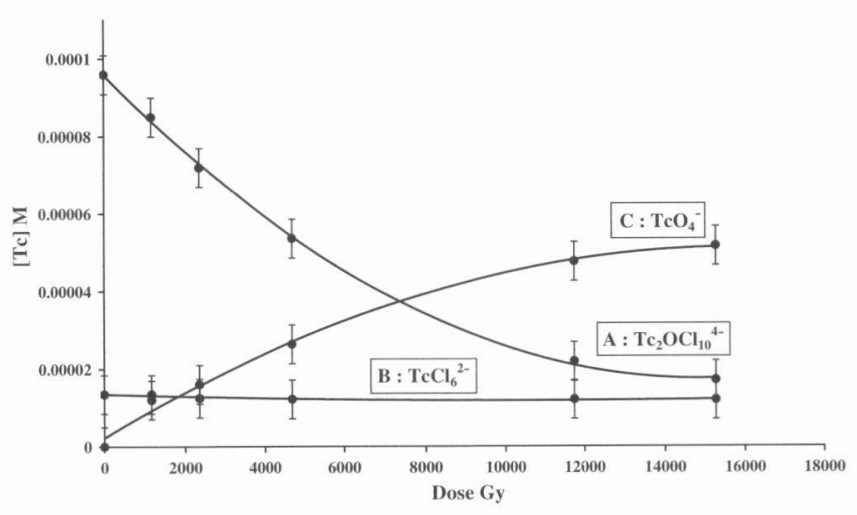

Figure 4. Concentration of $\mathrm{Tc}$ species as a function of dose during alpha irradiation of a $\mathrm{Tc}_{2} \mathrm{OCl}_{10}{ }^{4-} / \mathrm{TcCl}_{6}{ }^{2-}$ mixture. Operating conditions: $\left[\mathrm{Cl}^{-}\right]=3 \mathrm{M}, \mathrm{pH}=0.3$; atmosphere argon. Dose rate: 117.43 Gy.min ${ }^{-1} . \mathbf{A}: \mathrm{Tc}_{2} \mathrm{OCl}_{10}{ }^{4-}, \mathbf{B}: \mathrm{TcCl}_{6}{ }^{2-}$ and $\mathbf{C}: \mathrm{TcO}_{4}^{-}$.

TABLE 1: G Values for $\mathrm{TcO}_{4}^{--}, \mathrm{TcCl}_{6}{ }^{2-}$ and $\mathrm{Tc}_{2} \mathrm{OCl}_{10}{ }^{4-}$ in 3 $\mathrm{M}$ Chloride, $\mathrm{pH}=\mathbf{0 . 3}$ Under Alpha Radiation

\begin{tabular}{lc}
\hline Compound & $\mathrm{G}\left(\mathrm{mol} . \mathrm{J}^{-1}\right)$ \\
\hline $\mathrm{Tc}_{2} \mathrm{OCl}_{10}{ }^{4-}$ & $-9.05 .10^{-9}$ \\
$\mathrm{TcCl}_{6}{ }^{2-}$ & $-2.70 .10^{-10}$ \\
$\mathrm{TcO}_{4}{ }^{-}$ & $1.02 .10^{-8}$ \\
\hline
\end{tabular}

Dose rate: $117.43 \mathrm{~Gy} \cdot \mathrm{min}^{-1}$, argon atmosphere

of 28.55 Gy.min ${ }^{-1}$. During this experiment, the Tc concentration was measured using liquid scintillation after filtration through a $0.2 \mu \mathrm{m}$ membrane filter. The changes of absorption spectra during irradiations are presented in Figure 5 and the evolution of Tc species in Figure 6.

These figures reveal the complete oxidation of Tc(IV) species to Tc(VII) after a dose of $1713 \mathrm{~Gy}$. The initial radiolytic yield for the soluble Tc species are presented in Table 2.

During this experiment the concentration of $\mathrm{H}_{2} \mathrm{O}_{2}$ was determined using Ghormley's method (Figure 7). The value of $\left[\mathrm{H}_{2} \mathrm{O}_{2}\right]$ produced in presence of $\mathrm{Tc}(\mathrm{IV})$ was compared to the value obtained without Tc. The initial radiolytic yield of $\mathrm{H}_{2} \mathrm{O}_{2}$ without Tc was then determined: $\mathrm{G}\left(\mathrm{H}_{2} \mathrm{O}_{2}\right)=1.23 \cdot 10^{-7}$ mol. $\mathrm{J}^{-1}$. Meanwhile, in presence of $\mathrm{Tc}(\mathrm{IV}), \mathrm{H}_{2} \mathrm{O}_{2}$ or $\mathrm{OH}$. radicals were completely consumed in a dose range from $0 \mathrm{~Gy}$ to $400 \mathrm{~Gy}$.

3.4. Irradiation of a $\mathrm{TcCl}_{6}{ }^{2-} / \mathrm{TcCl}_{5}\left(\mathrm{H}_{2} \mathrm{O}\right)^{-} / \mathrm{Tc}_{2} \mathrm{OCl}_{10}{ }^{4-} \mathrm{mix}-$ ture under constant current. Aim of this experiment is to study the behaviour of Tc(IV) complexes during alpha irradiation under reducing potential: a mixture $\mathrm{TcCl}_{6}{ }^{2-} / \mathrm{TcCl}_{5}\left(\mathrm{H}_{2} \mathrm{O}\right)^{-} /$ $\mathrm{Tc}_{2} \mathrm{OCl}_{10}{ }^{4-}$ was irradiated in a $3 \mathrm{M}$ chloride solution $(\mathrm{pH}=1)$ with a dose yield of $34.40 \mathrm{~Gy} \cdot \mathrm{min}^{-1}$ under a constant courant (i $=-500 \mu \mathrm{A})$. During irradiation, the electrochemical potential fluctuated between $-420 \mathrm{mV}$ and $-450 \mathrm{mV} /(\mathrm{Ag} / \mathrm{AgCl})$. The

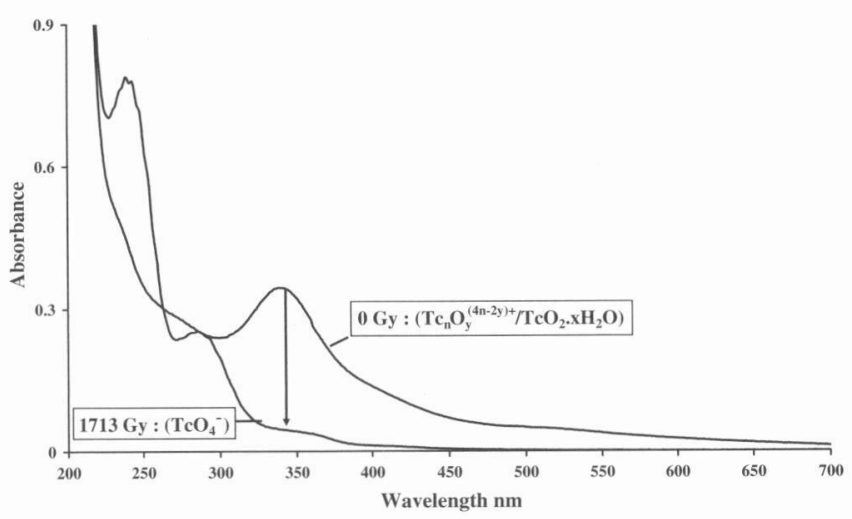

Figure 5. Change of absorption spectra of a $\mathrm{TcO}_{2} \cdot \mathrm{xH}_{2} \mathrm{O} / \mathrm{Tc}_{\mathrm{n}} \mathrm{O}_{\mathrm{y}}{ }^{(4 \mathrm{n}-2 \mathrm{y})+}$ mixture during alpha irradiation. Operating conditions: dose rate: $28.55 \mathrm{~Gy} \mathrm{~min}^{-1}$; atmosphere argon; $[\mathrm{Tc}]=9.9 .10^{-5} \mathrm{M},\left[\mathrm{Cl}^{-}\right]=3 \mathrm{M}, \mathrm{pH}$ $=2.5$; doses: 0 Gy and $1713 \mathrm{~Gy}$.

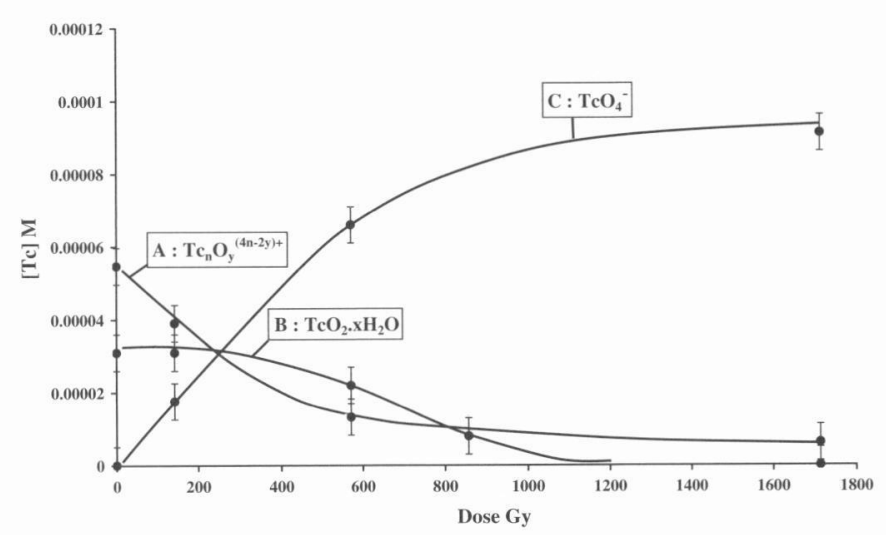

Figure 6. Concentration of $\mathrm{Tc}$ species as a function of dose during alpha irradiation of a $\mathrm{TcO}_{2} \cdot \mathrm{xH}_{2} \mathrm{O} / \mathrm{Tc}_{\mathrm{n}} \mathrm{O}_{\mathrm{y}}{ }^{(4 \mathrm{n}-2 \mathrm{y})+}$ mixture. Operating conditions: $\left[\mathrm{Cl}^{-}\right]=3 \mathrm{M}, \mathrm{pH}=2.5$; atmosphere argon. Dose rate: 28.55 Gy.min ${ }^{-1} \cdot \mathbf{A}: \mathrm{Tc}_{\mathrm{n}} \mathrm{O}_{\mathrm{y}}{ }^{(4 \mathrm{n}-2 \mathrm{y})+}, \mathbf{B}: \mathrm{TcO}_{2} \cdot \mathrm{xH}_{2} \mathrm{O}$ and $\mathbf{C}: \mathrm{TcO}_{4}^{-}$.

TABLE 2: G Values for $\mathrm{TcO}_{4}{ }^{-}$and $\mathrm{Tc}_{\mathrm{n}} \mathrm{O}_{\mathrm{y}}{ }^{(4 \mathrm{n}-2 \mathrm{y})+}$ in $3 \mathrm{M}$ Chloride ( $\mathrm{pH}=2.5$ ) Under Alpha Radiation

\begin{tabular}{lr}
\hline Compound & $\mathrm{G}\left(\mathrm{mol} . \mathrm{J}^{-1}\right)$ \\
\hline $\mathrm{Tc}_{\mathrm{n}} \mathrm{O}_{\mathrm{y}}{ }^{(4 \mathrm{n}-2 \mathrm{y})+}$ & $-1.09 .10^{-7}$ \\
$\mathrm{TcO}_{4}{ }^{-}$ & $1.12 .10^{-7}$ \\
\hline
\end{tabular}

Dose rate: 28.55 Gy. $\mathrm{min}^{-1}$, argon atmosphere

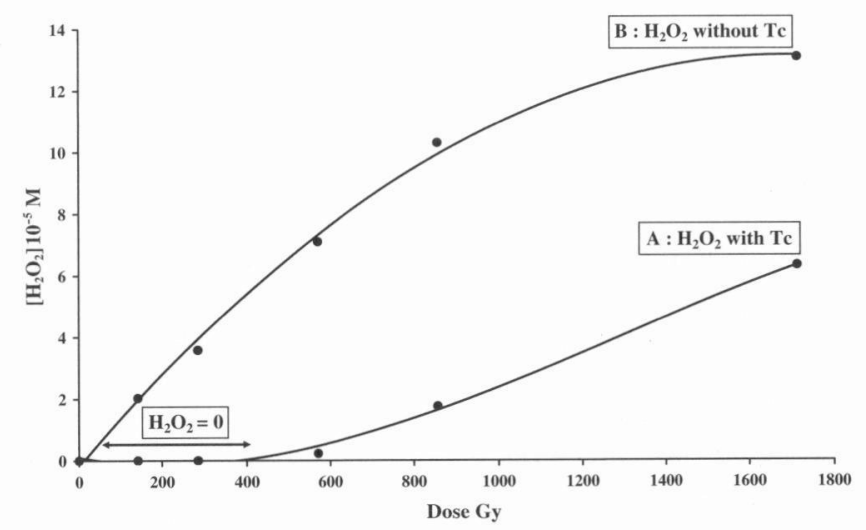

Figure 7. Concentration of produced $\mathrm{H}_{2} \mathrm{O}_{2}$ with $\mathrm{A}$ ) and $\mathrm{B}$ ) for in absence and in presence of Te(IV) during irradiation of a $3 \mathrm{M}$ chloride solution $(\mathrm{pH}=2.5)$; atmosphere argon. Dose rate $28.55 \mathrm{~Gy} \cdot \mathrm{min}^{-1}$.

changes of absorption spectra during irradiations are presented in Figure 8 and the evolution of Tc species in Figure 9. Analyses of Figure 8 and 9 reveal that the electrochemical potential can not impede the oxidation of Tc(IV) to Tc(VII). The experimental yields of Tc species are presented in Table 3 . 


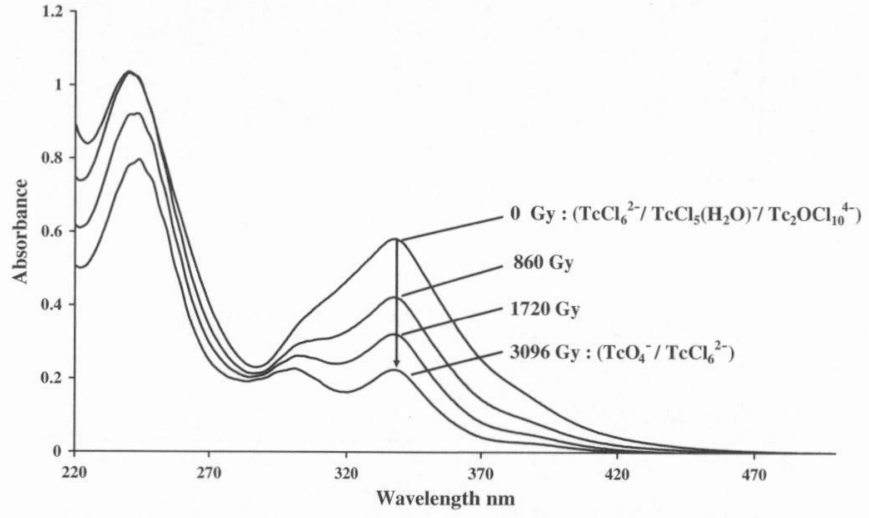

Figure 8. Change of absorption spectra of a $\mathrm{TcCl}_{6}{ }^{2-} / \mathrm{TcCl}_{5}\left(\mathrm{H}_{2} \mathrm{O}\right)^{-} /$ $\mathrm{Tc}_{2} \mathrm{OCl}_{10}{ }^{4-}$ mixture during alpha radiation under a constant current (i $=-500 \mu \mathrm{A}$ ). Operating conditions: dose rate: $34.40 \mathrm{~Gy} \cdot \mathrm{min}^{-1}$; atmosphere argon; $[\mathrm{Tc}]=8.10^{-5} \mathrm{M},\left[\mathrm{Cl}^{-}\right]=3 \mathrm{M}, \mathrm{pH}=1$; doses: 0 Gy, 860 Gy, 1720 Gy and 3096 Gy.

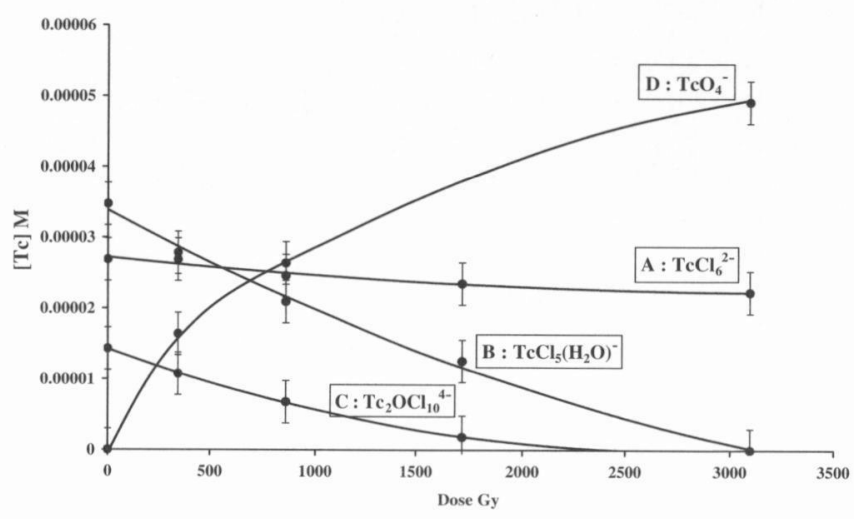

Figure 9. Concentration of Tc species as a function of dose during alpha irradiation of a $\mathrm{TcCl}_{6}{ }^{2-} / \mathrm{TcCl}_{5}\left(\mathrm{H}_{2} \mathrm{O}\right)^{-} / \mathrm{Tc}_{2} \mathrm{OCl}_{10}{ }^{4-}$ mixture under a constant current $(\mathrm{i}=-500 \mu \mathrm{A})$. Operating conditions: $\left[\mathrm{Cl}^{-}\right]=3 \mathrm{M}$, $\mathrm{pH}=1$; atmosphere argon. Dose rate: $34.40 \mathrm{~Gy} \mathrm{~min}^{-1} . \mathbf{A}: \mathrm{TcCl}_{6}{ }^{2-}, \mathbf{B}$ : $\mathrm{TcCl}_{5}\left(\mathrm{H}_{2} \mathrm{O}\right)^{-}, \mathbf{C}: \mathrm{Tc}_{2} \mathrm{OCl}_{10}{ }^{4-}$ and $\mathbf{D}: \mathrm{TcO}_{4}^{-}$.

TABLE 3: G Values for $\mathrm{TcO}_{4}{ }^{-}, \mathrm{TcCl}_{6}{ }^{2-}, \mathrm{Tc}_{2} \mathrm{OCl}_{10}{ }^{4-}$ and $\mathrm{TcCl}_{5}\left(\mathrm{H}_{2} \mathrm{O}\right)^{-}$in $3 \mathrm{M}$ Chloride $(\mathbf{p H}=1)$ During Alpha Radiation Under a Constant Current $(i=-500 \mu \mathrm{A})$

\begin{tabular}{lc}
\hline Compound & $\mathrm{G}\left(\mathrm{mol} . \mathrm{J}^{-1}\right)$ \\
\hline $\mathrm{TcCl}_{6}{ }^{2-}$ & $-2.8 .10^{-9}$ \\
$\mathrm{Tc}_{2} \mathrm{OCl}_{10}{ }^{4-}$ & $-8.66 .10^{-9}$ \\
$\mathrm{TcCl}_{5}\left(\mathrm{H}_{2} \mathrm{O}\right)^{-}$ & $-1.58 .10^{-8}$ \\
$\mathrm{TcO}_{4}{ }^{-}$ & $2.98 .10^{-8}$ \\
\hline
\end{tabular}

Dose rate: 34.40 Gy. $\mathrm{min}^{-1}$, argon atmosphere

\section{Discussion}

We showed in this paper that under alpha irradiations, the $\mathrm{Tc}(\mathrm{IV})$ complexes in $3 \mathrm{M}$ chloride media undergo oxidation to $\mathrm{Tc}$ (VII). In the same medium, non irradiated solution of Tc(IV) complexes are stable against oxidation for times equivalent to those of irradiation experiments. Under alpha radiation, $\mathrm{TcCl}_{6}{ }^{2-}$ is the most stable and the species having cores of the $[\mathrm{Tc}-\mathrm{O}-\mathrm{Tc}]^{6+}$ and $\left[\mathrm{Tc}(\mu-\mathrm{O})_{2} \mathrm{Tc}\right]^{4+}$ structures were oxidized easily.

The determination of the initial radiolytic yields allows to classify the $\mathrm{Tc}(\mathrm{IV})$ complexes according to their stabilities: $\mathrm{TcCl}_{6}{ }^{2-}>\mathrm{Tc}_{2} \mathrm{OCl}_{10}{ }^{4-}>\mathrm{TcCl}_{5}\left(\mathrm{H}_{2} \mathrm{O}\right)^{-}>\mathrm{Tc}_{\mathrm{n}} \mathrm{O}_{\mathrm{y}}{ }^{(4 \mathrm{n}-2 \mathrm{y})+}$.

This order suggested that the stability of Tc(IV) complexes depends on the number of oxygen and chlorine atoms in the structure. The presence of chlorine atoms in the structure can increase the stability of the $\mathrm{Tc}(\mathrm{IV})$ complexes, which is due to the electron donation capability of chlorine atoms. It is noteworthy that this phenomena has already been observed for rhenium $^{15}$ : the chlorinated $\operatorname{Re}(\mathrm{IV})$ complexes are obviously more stable than oxygenated Re(IV) complexes. Furthermore, literature data reveal that the $\mathrm{Tc}(\mathrm{VII}) / \mathrm{Tc}(\mathrm{IV})$ potential value depends on the number of chlorine atoms in the Tc(IV) structure: this potential is equal to $0.595 \mathrm{~V} / \mathrm{ENH}$ for $\mathrm{Tc}(\mathrm{IV})=\mathrm{TcO}(\mathrm{OH})_{2}$ (Ref. 16) and $0.849 \mathrm{~V} / \mathrm{ENH}$ for $\mathrm{Tc}(\mathrm{IV})=\mathrm{TcCl}_{5}\left(\mathrm{H}_{2} \mathrm{O}\right)^{-17}$. Thus, the increasing of $\mathrm{Tc}(\mathrm{VII}) / \mathrm{Tc}(\mathrm{IV})$ potential value with the number of chlorine atoms can also explain the relative stability of the Tc(IV) complexes.

Consequently, the experiment performed in $\left[\mathrm{Cl}^{-}\right]=3 \mathrm{M}, \mathrm{pH}$ $=1$ showed that $\mathrm{TcCl}_{6}{ }^{2-}$, which exhibits six chlorine atoms in its structure, is the most stable of Tc(IV) complexes whereas $\mathrm{TcCl}_{5}\left(\mathrm{H}_{2} \mathrm{O}\right)^{-}$and $\mathrm{Tc}_{2} \mathrm{OCl}_{10}{ }^{4-}$ with each one five chlorine atoms/ $\mathrm{Tc}$ are less stable. Between these two compounds, $\mathrm{TcCl}_{5}\left(\mathrm{H}_{2} \mathrm{O}\right)^{-}$ is less stable than $\mathrm{Tc}_{2} \mathrm{OCl}_{10}{ }^{4-}$, which is probably due to the presence of $\pi$ bonding in the [Tc-O-Tc ${ }^{6+}$ structure $^{8}$ which stabilizes more strongly the valence IV than the $\mathrm{H}_{2} \mathrm{O}$ ligand of $\mathrm{TcCl}_{5}\left(\mathrm{H}_{2} \mathrm{O}\right)^{-}$.

In a $\left[\mathrm{Cl}^{-}\right]=3 \mathrm{M}$ solution $(\mathrm{pH}=2.5)$, the measurement of $\left[\mathrm{H}_{2} \mathrm{O}_{2}\right]$ in absence and presence of Tc(IV) have proved that this compound is involved in the radiolytic oxidation of Tc(IV), which corresponds to the previous studies realised under gamma radiation. ${ }^{5,18}$ Among the reaction proposed,,$^{18}$ one is the oxidation of $\mathrm{Tc}(\mathrm{IV})$ to $\mathrm{Tc}(\mathrm{V})$ followed by disproportionation of $\mathrm{Tc}(\mathrm{V})$ to $\mathrm{Tc}(\mathrm{VI}), \mathrm{Tc}(\mathrm{IV})$ and $\mathrm{Tc}(\mathrm{VII})$ :

$$
\begin{aligned}
\mathrm{Tc}(\mathrm{IV})+\mathrm{H}_{2} \mathrm{O}_{2} & \rightarrow \mathrm{Tc}(\mathrm{V})+\mathrm{OH}^{\cdot}+\mathrm{OH}^{-} \\
2 \mathrm{Tc}(\mathrm{V}) & \rightarrow \mathrm{Tc}(\mathrm{VI})+\mathrm{Tc}(\mathrm{IV}) \\
2 \mathrm{Tc}(\mathrm{VI}) & \rightarrow \mathrm{Tc}(\mathrm{VII})+\mathrm{Tc}(\mathrm{VI})
\end{aligned}
$$

Nevertheless, if oxidation of Tc(IV) to Tc(VII) occurs exclusively according to (1), (2) and (3), it implies that $\mathrm{G}(\mathrm{Tc}(\mathrm{VII})=$ $(1 / 2) \mathrm{G}\left(\mathrm{H}_{2} \mathrm{O}_{2}\right)$. Considering the experimentally determined $\mathrm{G}(\mathrm{Tc}(\mathrm{VII}))$ and $\mathrm{G}\left(\mathrm{H}_{2} \mathrm{O}_{2}\right)$ values: $1.1210^{-7}$ mol.J $\mathrm{J}^{-1}$ and $1.2310^{-7}$ mol. $J^{-1}$, respectively, it appeared that $\mathrm{G}\left(\mathrm{Tc}(\mathrm{VII})>(1 / 2) \mathrm{G}\left(\mathrm{H}_{2} \mathrm{O}_{2}\right)\right.$ : this result indicated that other mechanisms than (1), (2) and (3) took place in the $\mathrm{Tc}(\mathrm{IV})$ oxidation.

Furthermore, irradiation of $\mathrm{NaCl}$ solution leads to formation of chlorinated species ${ }^{19}: \mathrm{Cl}_{2}{ }^{-}, \mathrm{Cl}_{2}$ and $\mathrm{Cl}_{3}{ }^{-}$, these species may also be involved in $\mathrm{Tc}(\mathrm{IV})$ oxidation .

It has been discussed ${ }^{5}$ that under gamma radiation, $\mathrm{Cl}_{2}{ }^{-}$is involved in Tc(IV) oxidation. The mechanisms proposed are listed below:

$$
\begin{aligned}
\mathrm{Tc}(\mathrm{IV})+\mathrm{Cl}_{2}{ }^{-} & \rightarrow \mathrm{Tc}(\mathrm{V})+2 \mathrm{Cl}^{-} \\
\mathrm{Tc}(\mathrm{V})+\mathrm{Cl}_{2}{ }^{-} & \rightarrow \mathrm{Tc}(\mathrm{VI})+2 \mathrm{Cl}^{-} \\
\mathrm{Tc}(\mathrm{VI})+\mathrm{Cl}_{2}{ }^{-} & \rightarrow \mathrm{Tc}(\mathrm{VII})+2 \mathrm{Cl}^{-}
\end{aligned}
$$

Considering the presence of $\mathrm{H}_{2} \mathrm{O}_{2}$ and $\mathrm{Cl}_{2}^{-}$, it was proposed that $\mathrm{G}$ (Tc(VII) can be formulated as :

$$
\mathrm{G}\left(\mathrm{Tc}(\mathrm{VII})=1 / 3 \mathrm{G}\left(\mathrm{Cl}_{2}{ }^{-}\right)+2 / 3 \mathrm{G}\left(\mathrm{H}_{2} \mathrm{O}_{2}\right)\right.
$$

However, in the present work, we think that the mechanism described in (4), (5) and (6) may occur in the Tc(IV) oxidation. Nevertheless, the presence of $\mathrm{Cl}_{3}{ }^{-}$during alpha irradiation, indicates that this species may also be involved in Tc(IV) oxidation. Radiolytic oxidation of Tc(IV) in concentrated chloride media can be considered as a complex process. And for clarifying the mechanisms of this oxidation, further experiments by pulsed alpha radiolysis have to be performed in order to specify the different chlorinated radicals in absence and presence of Tc.

\section{Conclusion}

This work showed that among the Tc(IV) complexes under alpha irradiation $\mathrm{TcCl}_{6}{ }^{2-}$ is stable whereas the other complex undergo oxidation to $\mathrm{TcO}_{4}{ }^{-}$. This work has permitted to classify the Tc(IV) complexes as function of their stabilities under alpha radiation. 
- It showed that $\mathrm{H}_{2} \mathrm{O}_{2}$ is involved in the radiolytic oxidation of Tc(IV)

- The experiments realised under electrochemical potential proved that in spite of a reducing potential the radiolytic oxidation of Tc(IV) can still occur. This result indicated that in a deep storage media, without organic species, the mobility of Tc can be dependant on $\mathrm{TcO}_{4}^{-}$produced by the radiolytic oxidation of $\mathrm{Tc}(\mathrm{IV})$ compounds.

For understanding better the oxidation mechanisms, it will be interesting to perform experiments by alpha pulsed radiolysis in presence and absence of Tc(IV) and determine the role of chlorinated radicals. In this aim, the cell developed in this work will be used for further experiments on ${ }^{99} \mathrm{Tc}$ at the future cyclotron of Nantes.

Acknowledgements. Authors want to thank G. Blondiaux director of CERI laboratory (CNRS-Orleans) and his staff for providing beam time and for technical assistance during experiment.

We also acknowledge M. Dialinas and T. Milleto (SUBATECHNantes) for technical advices and the fabrication of the electrochemical cell.

\section{References}

(1) K. Ben-Said, Y. Seimbille, M. Fattahi, C. Houée-Levin, and J. C. Abbé, J. Appl. Radiat. Isot. 54, 45 (2001).

(2) W. W. Lukens, J. J. Bucher, N. M. Edelstein, and D. K. Shuh, Environ. Sci. Technol. 36, 1124 (2002).

(3) T. Sekine, H. Narushima, Y. Kino, H. Kudo, M. Lin, and Y.
Katsumura, Radiochim. Acta 90, 611 (2002).

(4) T. Sekine, H. Narushima, T. Suzuki, T. Takayama, H. Kudo, M. Lin, and Y. Katsumura, Colloids and Surfaces A: Physicochem. Eng. Aspects. 249, 105 (2004).

(5) M. Fattahi, L. Vichot, C. Houee-Levin, F. Poineau, and B. Grambow, Radiochim. Acta (in press).

(6) M. Lefort, Bull. Soc. Chim. Fr. 882 (1963).

(7) L. Vichot, M. Fattahi, C. Musikas, and B. Grambow, Radiochim. Acta 91, 263 (2003).

(8) F. Poineau, M. Fattahi, G. Montavon, and B. Grambow, Radiochim. Acta (Submitted).

(9) T. Mennecart, Thèse université de Nantes (2004).

(10) K. Ferrand, Thèse université de Nantes (2004).

(11) C. Corbel, G. Sattonay, J. F. Lucchini, C. Ardois, M. F. Barthe, F. Huet, P. Dehaudt, B. Hickel, and C. Jégou, Nucl. Inst. Meth. Phys. Res. B. 179, 225 (2001)

(12) H. Fricke and E. J. Hart, Radiation dosimetry. (Academy Press, New York 1966).

(13) A. O. Allen, C. J. Hochanadel, J. A. Ghormley, and T. W. Davis, J. Phys. Chem. 56, 575 (1952).

(14) R. K. Broszkiewicz, Radiat. Phys. Chem. 15, 133 (1980).

(15) J. A. Casey and K. R. Murman, Inorganic Chemistry. 6, 1055 (1967).

(16) J. A. Rard, URCL-53440, Lawrence Livermore National Laboratory, Livermore, California (1983).

(17) K. Ben-said, M. Fattahi, C. Musikas, and J. C. Abbé, Radiochim. Acta 83, 195 (1998).

(18) L. Vichot, Thèse université de Paris XI (2001).

(19) T. Lundstrom, H. Christensen, and K. Sehested, Radia. Phys. Chem. 61, 109 (2001). 